American Journal of Geoscience 1 (1): 21-26, 2010

ISSN 1948-9846

(C) 2010 Science Publications

\title{
Groundwater Resources Management in Various Scenarios Using Numerical Model
}

\author{
${ }^{1}$ S. Askari Marnani, ${ }^{1}$ M. Chitsazan, ${ }^{2}$ Y. Mirzaei and ${ }^{3}$ B. Jahandideh \\ ${ }^{1}$ Department of Hydrogeology, Shahid Chamran University, \\ Golestan Blvd, College of Science, Ahvaz, Iran \\ ${ }^{2}$ Department of Hydrology, \\ ${ }^{3}$ Department of Geology, \\ Shahid Chamran University, Ahvaz, Iran
}

\begin{abstract}
Problem statement: Iran is an arid country and only small percent of its water demand is met by rainfall. At present, about 55\% of Iran's water being supplied by aquifers and $45 \%$ from surface water. Population growth, joint with economic development and rapid growth in industry and farming, has caused a vast increase in demand for water in Iran. But the slow recharging aquifers have not been able to cope with new condition. Approach: In this context, the importance of control and optimum utilization of groundwater has been realized by Iranian and groundwater models because of their high effectiveness and less expenses than other methods have been developed and us end by hydro geologists as a water source management tool. Results: For this purpose, the quantitative model of the groundwater of Firozabad plain, with area of $240 \mathrm{~km}^{2}$, which is located $100 \mathrm{~km}$ distant from the southwest of Shiraz, is prepared. MODFLOW, GMS, groundwater modeling system, was used to build a groundwater flow model to simulate the behavior of the flow system under different stresses for one year period (2006-2007) under unsteady condition. First, a conceptual model was set up using simple GIS tools. Conclusion: The numerical model was generated and, transient data from observation wells was used to calibrate the model. Following this, the transient model was validated by using observation data for the period 2007-2008 .Then; the completed MODFLOW model was ready for simulation runs. The results for the various scenarios including predicting the status of water level in next 5 years, drilling new production wells and predicting the status of groundwater under drought conditions was analyzed in Firozabad plain.
\end{abstract}

Key words: Modeling, mathematical model, finite differences, GMS software, MODFLOW 2000, calibration

\section{INTRODUCTION}

Executive sectors have initiated widespread actions in order to developing basic studies, generating observation and exploration wells in recent years which can be considered as a start point for water resources preservation. However, with regard to current conditions and research funds limitations, unfortunately, recognizing a groundwater aquifer system behavior and conducting a series of long term researches on any specific region might seem impossible. Meanwhile, utilizing simulators or models has found its preeminent position, expanding rapidly due to their high precision. The purpose of mathematical model of a groundwater aquifer is to simulate the real conditions of an aquifer using mathematical relations. If the simulation process of an aquifer is carried out with success, evaluating aquifer changes, place, amount and time of aquifer discharge can simply be determined. In other words, the effects of discharge and recharge in different circumstances can be predicted.

A model is a schema of reality and in connection with an existent system is based on different preview and assumption. In other words hydraulic and hydro geologic parameters used in a model are an estimation of real parameters in the field.

A model renders a general view of an aquifer and its conditions enabling the hydro-geologist or model maker to predict the model's response to probable different stresses as well as making appropriate decision.

Significance of groundwater model in obtaining optimum and reasonable results has been expressed by several scientists such as Owen et al. (1996); Christensen and Cooley (2003); Brewer et al. (2003); Tiedeman and Hill (2007); Hinkelmann (2005); Saghravani et al. (2010); and Rani and Chen (2010).

Corresponding Author: Sedigheh Askari Marnani, MSc of Hydrogeology, College of Science,

Shahid Chamran University, Golestan Blvd, Ahvaz, Iran.

Email: askary1122@yahoo.com, Phone: +989173054508 


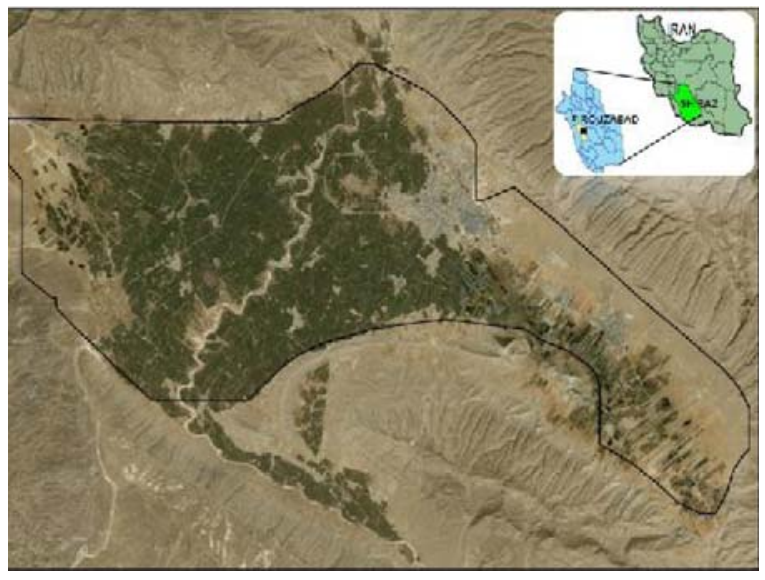

Fig. 1: The study area

The purpose of this study is to assess the groundwater resources of Firozabad plain using finite differences mathematical model. The mentioned plain is about $100 \mathrm{~km}$ south-western Shiraz, located between latitudes $28^{\circ} 36^{\prime}-28^{\circ} 45^{\prime}$ and longitudes $52^{\circ} 19^{\prime}-52^{\circ} 38^{\prime}$ (Fig. 1). This area is a Firozabad river sub basin with the river passing in the middle and bisecting the plain. The river recharges the plain at the outset while draining it at the end. The plain is $240 \mathrm{~km}^{2}$ in area and $2891 \mathrm{~m}$ as highest altitude in north-eastern heights and $1300 \mathrm{~m}$ as lowest in the south-eastern. According to the year 2010 statistics, a number of 1784 deep and semideep wells exist in the region providing the required water for drinking and agricultural purposes.

The plain bedrock consists of Fars group formations and the outcropped formations of the study area and adjacent zones chronologically include Hormoz series, Bangestan group, Pabde-Gorpey, Asmari, Gradual unit, Gouri part of Mishan formation, Aghajari, Bakhtiari and quaternary sediments.

The plain is recharged through northern, northeastern, eastern, south-eastern and western heights and groundwater flow direction is from east, north-eastern, north and north-western of the plain to its south-western and central areas. The most important inputs to groundwater of the plain include rainfall influx, underground recharge and irrigation return flows and the most important out going factor is production wells.

GMS software was used to simulate the Firozabad plain aquifer. GMS is an interface that incorporates several numerical models, as well as graphical tools, to help obtain and visualize results (EMS-I, 2005). This software combines different modeling tools, so called modules, in one software package. One of GMS's main modules is MODFLOW (McDonald and Harbaugh,
1988), a three-dimensional, cell-centred, finitedifference saturated flow model, developed by the US Geological Survey in 1984. GMS employs the latest version of MODFLOW from the year 2000.

\section{MATERIALS AND METHODS}

Producing groundwater model has been considered so important that some postulate it as crucial in vital decision makings and management analyses (Brewer et al., 2003). Mathematical models and software GMS and GIS were utilized to study the groundwater flow system of Firozabad plain aquifer. As the first step to do this, the entire existing information such as geological, climatologic and hydrologic information, satellite images processing results, exploration studies, hydraulic and hydrogeologic studies and budget, were introduced to GIS database and after inserting the GIS database stored information to GMS software, the conceptual model was generated. Subsequent to generation of conceptual model, it was converted into mathematical model arrays and the ultimate model was completed into run phase. The GMS software uses code MODFLOW 2000 to generate models.

Using GMS to generate groundwater flow model through a conceptual model is one of the most important privileges of it. Producing conceptual model includes determination of geometry, kind and constitutive materials of the aquifer. The first stage in generating Firozabad plain conceptual model is to insert the region scanned image into the GMS environment and geo-reference it. Afterwards, model zone boundary was depicted and rest of parameters such as boundary conditions of the model, depletion of groundwater by production wells, recharge, hydraulic characteristics and river conditions were determined as separate layers with dissimilar characteristic (Thoma and Nelson, 2008).

Spatial discretization of the aquifer was down regarding issues like geological status, topography, groundwater potential map and dimensions of the study area and a grid consisting of cells with $500 \times 500$ square meters dimension in 38 rows and 65 columns were produced and parameters such as bed rock, topography, hydraulic conductivity $(\mathrm{K})$ values, Specific Yield (SY), General Head Boundary (GHB), production wells, amounts of surface recharge and initial head were allocated to each grid cell through the conceptual model approach.

In the Firozabad region, the hydraulic conductivity was determined according to pumping test information in 13 exploration wells and the specific yield according to aquifer materials and well logging being generalized to the entire plain using the kriging interpolation function in GIS software. Considering the obtained results, the initial values of hydraulic 


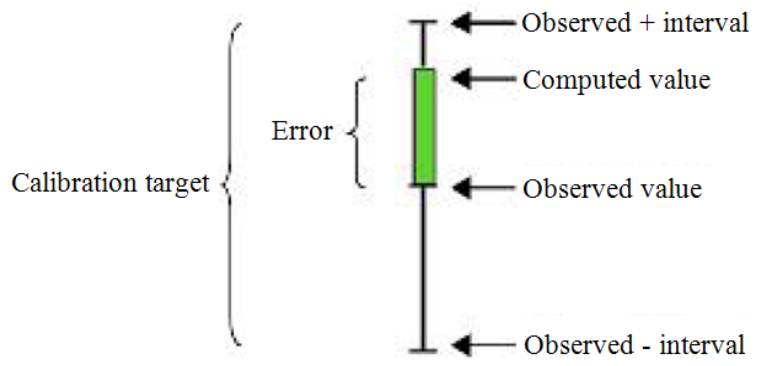

Fig. 2: Calibration target (Environmental Modeling Research Laboratory, 1999)

conductivities in 7 zones and the initial values of specific yield in 5 zones were inserted into the model grid.

Time discretization in the study area was done according to stress periods that were selected from accessible hydro-geologic data and the plain unit hydrograph. Hence, the mentioned plain was simulated in an unsteady condition during a one year time period (from September 2006-August 2007) in which 12 stress periods can be observed.

Application of such data caused so many errors in calculation of changes in the water level. In order to correct those errors occurred and to attain coefficients closer to reality, model calibration through both trial and error and automatic via PEST code methods was performed. In PEST code, region parameters are optimized using inverse methods. Optimization purpose is to reach a point in which Root Mean Square Error (RMSE) is undermost. In this package, parameters need to be optimized were specified at first and an initial value were allocated to each defining the tolerable range of changes (tolerance). To achieve the lowest RMSE, changing and repetitious implementation of the parameters was done.

Considering proper initial values is of great significance when estimating parameters and unreal values would lead to unexpected results and unreasonable responses having no conformity with reality. The reason could be explained is parameters estimation being nonlinear causing parametric values estimated by the model to be dependent on initial values of the parameters.

Visual representation of error quantity resulted from observed and computed hydraulic head difference is another advantage of GMS. Thus, depicting a calibration target adjacent to each pizo meter, the calibration status after running the model could be recognized (Christensen and Cooley, 2003) (Fig. 2).

The colored bar indicates the calibration error having its centre on observed values. If the error falls into tolerable range of errors, the bar would appear

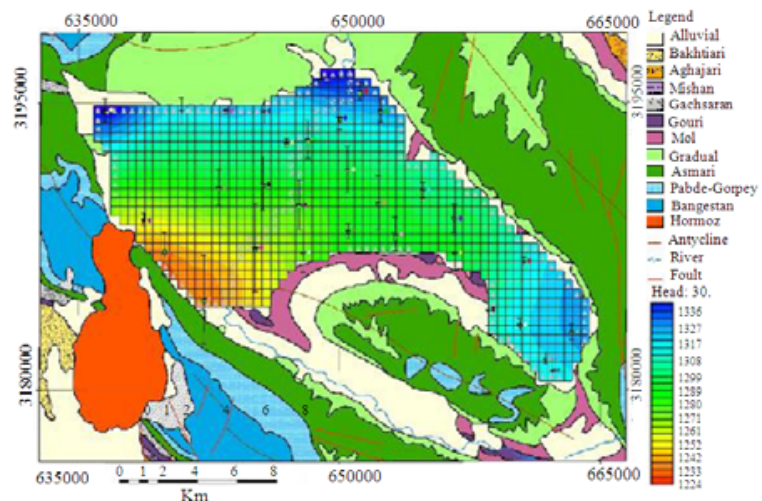

Fig. 3: Results of unsteady model calibration at the first stress period

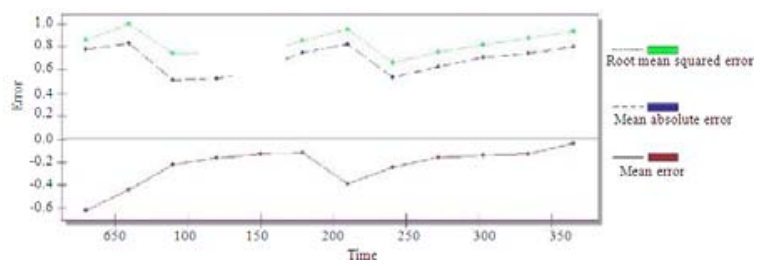

Fig. 4:RMSE in each stress period in an uns teady condition

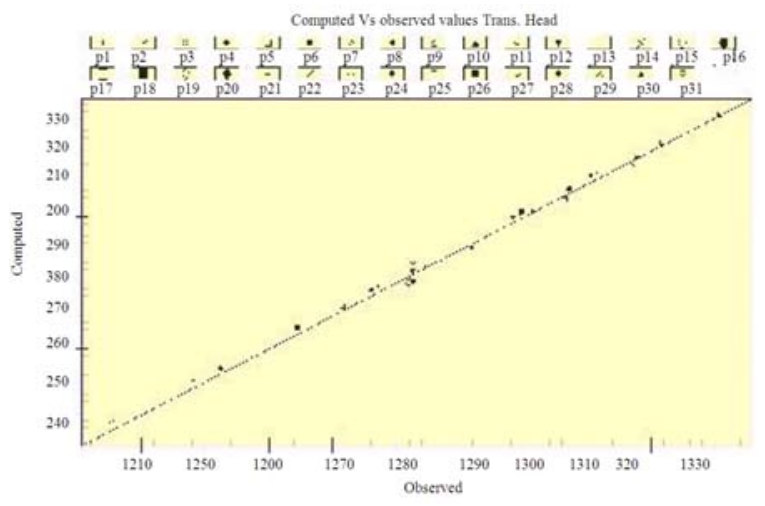

Fig. 5: Comparison of observed and calculated values related to first stress period verification for each one of observation wells

green and if it is less than $200 \%$ of tolerable range, it will turn yellow while being more than $200 \%$ of tolerable range, the bar would turn red (Brewer et al., 2003). Hence, using the colored bar, calibration status of piezo meters on the plain could simply be comprehended. Figure 3 depicts the results achieved from unsteady model calibration at the first stress period. 
Am. J. Geoscience 1 (1): 21-26, 2010

RMSE in each tension periods in unsteady status has been depicted in Fig. 4. In fact verification is done through examination of hydrodynamic coefficients $\mathrm{K}$ and SY obtained from model calibration. To assure accuracy of the model generated for Firozabad plain aquifer, plain calibration results were verified within a time period of 365 days from September 2007 to August 2008. An effort was made during verification process of Firozabad plain to make some permitted changes in variable parameters (e.g., pumping values) in order to eliminate some slight differences existing in some observed wells. Comparison of observed and calculated values related to first stress period verification for each one of observation wells has been showed in Fig. 5.

\section{RESULTS}

Quantitative assessment of groundwater is one of hydro-geologic study of plains purposes. Quantitative potential estimation is taken into consideration when some kind of imbalance appears in inputs and outputs of the region due to drought or illegal overproduction from the aquifer, which results in an increase in pumping costs of production wells or cause them to dry up. However, having knowledge of the region water budget, a proper and effective management for water production and supply could be exerted. If water budget is negative, groundwater overproduction would result in aquifer pollution and vulnerability due to water quality degradation as well as ground leakage. In this regard, options such as decreasing aquifer production, alteration of plantation style and artificial recharge plan could be considered.

One of the best features of GMS software is the ability to offer the plain groundwater budget. Budget calculation using Flow Budget Package of the model software is done subsequent to verification task. Having hydro-geological parameters generated and corrected by means of the model in an unsteady condition (in different periods), running the model calculated final budget of the Firozabad plain in an unsteady condition (2006-2007 period). Table 1 shows the water budget procured by the model in an unsteady status for the 12th stress period. Subtraction of Input (IN) and Outgoing (OUT) water storage amount in 12th stress period will provide the overall water budget of Firozabad plain in a one year period, estimated-17.8 million cubic meters.

After calculating Firozabad plain water budget, a variety of management scenarios were considered and budget changes occurred due to aquifer stresses were studied.
Table 1: Volumetric budget for entire model at and of time step 1 in 2006-2007 periods.

\begin{tabular}{ll}
\multicolumn{1}{c}{ Cumulative VOLUMES $\left(\mathrm{m}^{3}\right)$} & \multicolumn{1}{c}{ Rates of this time step $\left(\mathrm{m}^{3} /\right.$ day $)$} \\
\multicolumn{1}{c}{ IN } & \multicolumn{1}{c}{ IN } \\
Storage $=73256048.0$ & Storage $=239364.3125$ \\
Constant head $=0.0$ & Constant head $=0.0$ \\
Wells $=67224224.0$ & Wells $=139310.7031$ \\
River leakage $=0.0$ & River leakage $=0.0$ \\
Head dep bounds $=25180688.0$ & Head dep bounds $=29264.9199$ \\
Recharge $=125948888.0$ & Recharge $=339347.8438$ \\
TOTAL IN $=291609856.0$ & TOTAL IN $=747287.7500$ \\
\multicolumn{1}{c}{ OUT } & \multicolumn{1}{c}{ OUT } \\
Storage $=55470440.0$ & Storage $=28988.6641$ \\
Constant head $=0.0$ & Constant head $=0.0$ \\
Wells $=224289952.0$ & Wells $=641343.6250$ \\
River leakage $=0.0$ & River leakage $=0.0$ \\
Head dep bounds $=11843431.0$ & Head dep bounds $=747252.9375$ \\
Recharge $=0.0$ & Recharge $=0.0$ \\
TOTAL OUT $=291603808.0$ & TOTAL OUT $=747252.9375$ \\
IN-OUT $=6048.0$ & IN-OUT $=34.8125$ \\
PERSENT DISCREPANCY $=$ & PERSENT DISCREPANCY $=$ \\
0.0 & 0.0 \\
\hline
\end{tabular}

\section{DISCUSSION}

Drilling new production wells in the region: Due to existing negative budget, drilling a new production well in the region is not recommended.

Continuing current trend of production from aquifer for five next years: Calibrated model of plain groundwater was used to predict the water level status in five next years. To predict according to the current trend, data acquired in September 2006 was introduced to the model as initial conditions running the model for a time period of five years including 60 time steps from September 2006 to September 2011. Continuing current production trend, the plain water level has descended. Considering budget parameters, it would be obvious that 2009-2010 budget has a more negative status in comparison with 2006-2007 one (Table 2).

Figure 6 shows the predicted water level for Firozabad plain in September 2011.

Prediction of aquifer status in drought conditions: In order to study the aquifer status in drought tensions, Firozabad plain model was ran for a one year period considering the minimum rainfall of amount $210.7 \mathrm{~mm}$ per year that was observed in 1999-2000 (in a period of 11 years).

Model output results have been shown in Table 3. Considering these results, the annual water budget of Firozabad plain model is getting more negative due to drought conditions. Hence, if any proper management agenda is exerted in the region, the most optimization level in water and soil by altering or decreasing of plantation in water shortage conditions could be witnessed. 
Am. J. Geoscience 1 (1): 21-26, 2010

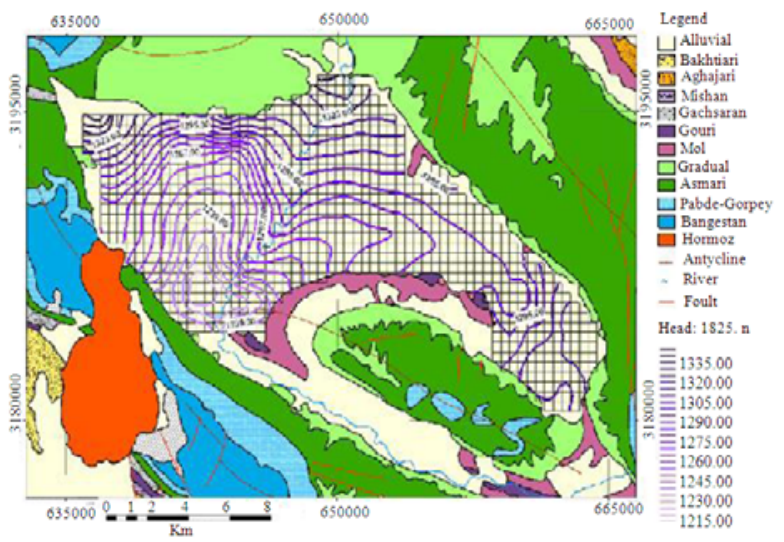

Fig. 6: 60th time step water level in continuation of current trend conditions

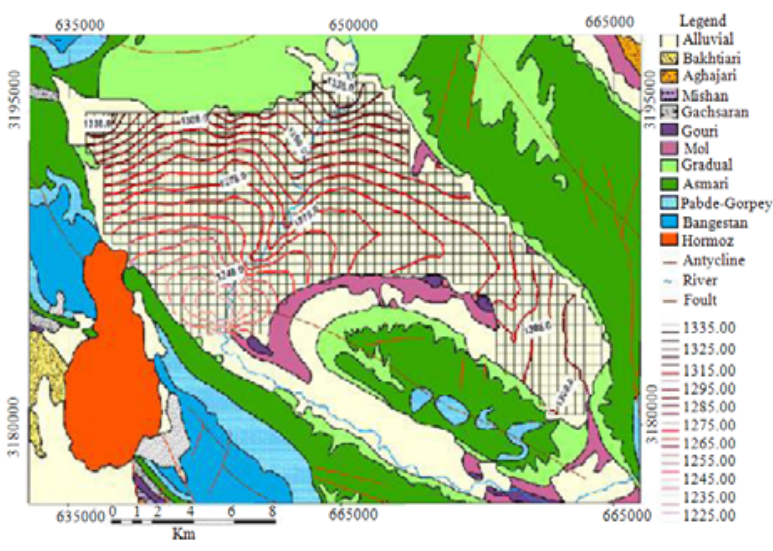

Fig. 7: Water level average map in drought conditions

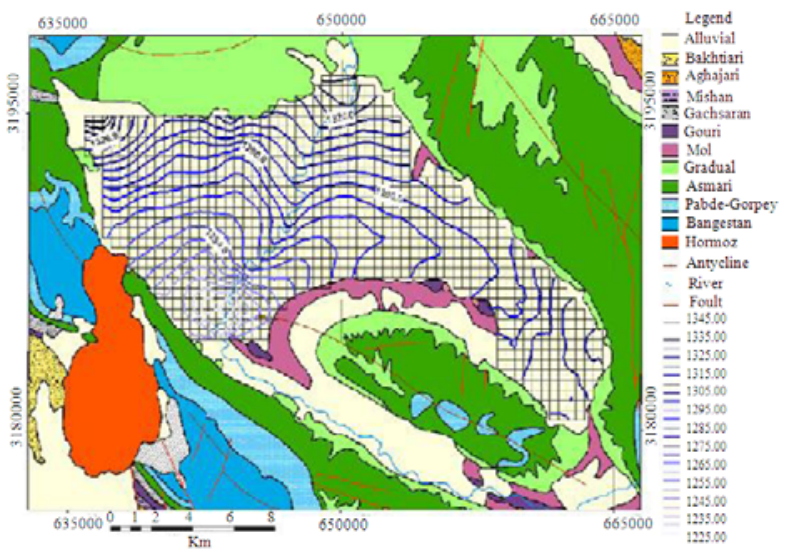

Fig. 8: Water level average map in wet period conditions

Fig. 7 shows the water level average of the region in drought conditions.
Table 2: Components and values of Firozabad plain model water budget in current trend conditions $\left(\mathrm{m}^{3}\right)$

\begin{tabular}{lrc}
\hline & \multicolumn{1}{l}{ IN } & OUT \\
\hline Wells and river & 47647466.19 & -204187460.00 \\
Recharge & 120018933.60 & - \\
Groundwater flow & 21074414.26 & -13705595.50 \\
SUM & 188740814.10 & -217893055.90 \\
OUT-IN & & -29152241.89 \\
\hline
\end{tabular}

Table 3: Water Budget components and values of Firozabad plain in drought conditions $\left(\mathrm{m}^{3}\right)$

\begin{tabular}{lrc}
\hline & \multicolumn{1}{c}{ IN } & OUT \\
\hline Wells and river & 57992038.98 & -212609004.30 \\
Recharge & 101395070.50 & - \\
Groundwater flow & 26694659.16 & -10253210.88 \\
SUM & 186081768.60 & -222862215.20 \\
OUT-IN & & -36780446.62 \\
\hline
\end{tabular}

Table 4: Firouzabad plain model's water budget components and values in wet period conditions $\left(\mathrm{m}^{3}\right)$

\begin{tabular}{lrc}
\hline & \multicolumn{1}{l}{ IN } & Out \\
\hline Wells and river & 58601837.75 & -215667541.20 \\
Recharge & 133675281.80 & - \\
Groundwater flow & 24612199.97 & -12336051.34 \\
SUM & 216889319.60 & -228003592.60 \\
OUT-IN & & -11114273.02 \\
\hline
\end{tabular}

Predicting aquifer status in wet period conditions: In order to study the aquifer status in wet period conditions, Firozabad plain model was ran for a one year term considering the average maximum rainfall amount $(654.5 \mathrm{~mm})$ in a period of 16 years $(1992-$ 2008). Table 4 shows the model's water budget components and values in wet period conditions. Figure 8 shows the region water level average in wet period conditions.

\section{CONCLUSION}

- 3D model of Firozabad plain is a mathematical representation of groundwater flow generated by GMS software using code MODFLOW 2000

- Producing conceptual model in map module is the first step to generate a model by means of GMS software. In fact, GMS gathers all the information required from GIS database stored information in order to generate the conceptual model and converts it to model arrays subsequent to generation of conceptual model in the map module

- Connecting GIS to hydrologic models is a logical and efficient task for the reason that manual gathering of huge amounts of required geographical information to produce groundwater model would need extensive time, cost and human resources. Also, using GIS capabilities in presentation of results as well as database management would be a considerable assistance to model calibration acceleration 
- Mathematical model is an efficient management tool for aquifer studies and prediction of different hydrologic and hydro-geologic tensions impact. Such a purpose is closer to reality when modeling and calibration phases are carried out successfully

- Regarding Firozabad groundwater model inputs and outgoes, the 2006-2007 period's water budget was calculated to be-17.8 million cubic meters:

- Due to existing negative budget of the plain and aquifer critical conditions, drilling a new production well in the region is not recommended

- Continuing current production trend, the plain water level has descended. Considering budget parameters, it would be obvious that the budget will have a more negative status in comparison with 2006-2007 one

- Firozabad plain groundwater budget in drought conditions (a minimum rainfall amount of 210.7 $\mathrm{mm}$ in 1999-2000 periods) was calculated-37 million cubic meters per year implying a critical condition for the aquifer

- Firozabad plain groundwater budget in wet conditions (regarding average of five maximum rainfall amounts in a period of 16 years 1992- 2008 that would be $654.5 \mathrm{~mm}$ ) was calculated about -11 million cubic meters per year.

\section{REFERENCES}

Brewer, K., T. Fogle, A. Stieve and C. Barr, 2003. Uncertainty Analysis with Site-Specific Groundwater Models: Experiences and Observations. http://www.osti.gov/bridge

Christensen, S. and R.L. Cooley, 2003. Experiences gained in testing a theory for modeling groundwater flow in heterogeneous media: In Calibration and Reliability in Groundwater Modeling: A few Steps Closer to Realing, K. Kovar and Z. Hrkal,(Eds.). IAHS pub. No. 277, p: 22-27.

EMS-I, 2005. Groundwater Modeling System, Environmental Modeling Systems, Inc., http://www.emsi.com/GMS/GMS_Overview/gms_overview.html on 2006-10-01
Environmental Modeling Research Laboratory, 1999. Groundwater Modeling System- GMS Reference Manua.

ftp://ftp.gtk.fi/mirrors/gms/gms/gms3.0/docs/refma n30.pdf

Hinkelmann, R., 2005. Efficient Numerical Methods and Information-Processing Techniques for Modeling Hydro- and Environmental Systems. 1st Edn., Springer, Berlin Heidelberg, New York, ISSN: 1613-7736, pp: 305.

McDonald, M.G. and A.W. Harbaugh, 1988. A Modular Three-Dimension Finite-Difference Groundwater Flow Model. US Geological Survey. Washington DC., pp: 875.

Owen, S.J., N.L. Jones and J.P. Holland, 1996. A comprehensive modeling environment for the simulation of groundwater flow and transport. Engineer. Comput., 12: 235-242. DOI: 10.1007/BF01198737

Rani, F.M. and Z.H. Chen, 2010. Numerical modeling of groundwater flow in karst aquifer, makeng mining area. Am. J. Environ. Sci., 6: 78-82. ISSN: 1553-345X

Saghravani, S.R., M. Sa'ari, I. Shahari, M.A. Zawawi, and E. Randjbaran, 2010. Simulation of phosphorus movement in unconfined aquifer by means of visual MODFLOW. J. Comput. Sci., 6: 446-449. ISSN: $1549-3636$

Thoma, M. and G. Nelson, 2008. Manual for Development of a Transient MODFLOW/MT3DMS/SEAWAT Simulation for the 2001 Tracer Test at the Boise Hydrogeophysical Research Site. In: Technical Report, BSU CGISS, 08-02.

Tiedeman, C.R. and M.C. Hill, 2007. Model Calibration and Issues Related to Validation, Sensitivity Analysis, Post-Audit, Uncertainty Evaluation and Assessment of Prediction Data Needs. Thangarajan, M., Groundwater (Eds.). Berlin, Springer, ISBN: 978-1-4020-5728-1 (HB), pp: 237-282. 